\title{
Tree-Ring Reconstruction of Bark Beetle Disturbances in the Picea schrenkiana Fisch. et Mey. Forests of Southeast Kazakhstan
}

\author{
Ann M. Lynch ${ }^{1, *}$, Nurjan S. Mukhamadiev ${ }^{2}$, Christopher D. O'Connor $^{3}{ }^{\circ}$, \\ Irina P. Panyushkina ${ }^{4}$ (D), Nursagim A. Ashikbaev ${ }^{2}$ and Abay O. Sagitov ${ }^{2}$ \\ 1 U.S. Forest Service, Rocky Mountain Research Station, 1215 E Lowell St., Tucson, AZ 85721, USA \\ 2 Research Institute of Plant Protection and Quarantine, Almaty 050070, Kazakhstan; \\ nurzhan-80@mail.ru (N.S.M.); ms.ank141@gmail.com (N.A.A.); A_Sagitov@mail.ru (A.O.S.) \\ 3 U.S. Forest Service, Rocky Mountain Research Station, Missoula, MT 59801, USA; \\ christopher.d.oconnor@usda.gov \\ 4 University of Arizona, Laboratory of Tree-Ring Research, Tucson, AZ 85721, USA; \\ ipanyush@email.arizona.edu \\ * Correspondence: ann.m.lynch@usda.gov; Tel.: +1-520-626-9582
}

Received: 28 August 2019; Accepted: 12 October 2019; Published: 17 October 2019

\begin{abstract}
Ips hauseri Reitter is the most important bark beetle on Picea schrenkiana in southeast Kazakhstan, but its biology, ecology, and outbreak dynamics are poorly known. We dendrochronologically reconstructed a 200-year history of disturbances in the Kazakh Tien Shan P. schrenkiana forests. Only localized, low-severity bark beetle events occurred during the reconstructed period, indicating that extensive high-severity bark beetle outbreaks have not occurred historically in the Tien Shan spruce forest, unlike bark beetle outbreaks in spruce forests in North America, Europe, and Russia. Disturbance frequency doubled after about 1965, probably due to warming climate. Results, combined with the failure of an outbreak to fully develop after blowdown events associated with hurricane-force windstorms in 2011, indicate that prolonged drought may be necessary to sustain I. hauseri outbreaks, or that year-to-year variation in the Tien Shan weather prevents outbreak development. I. hauseri is probably less aggressive than I. typographus, at least on their natural hosts within their natural ranges.
\end{abstract}

Keywords: bark beetles; Hauser's engraver; Schrenk's spruce; windstorm; blowdown; dendrochronology; Ips duplicatus; Ips hauseri; Ips sexdentatus; Ips typographus

\section{Introduction}

High-severity wind storms with heavy rains caused significant blowdown in spruce forests in the Tien Shan Mountains of southeastern Kazakhstan in May and June 2011. Large-scale blowdown events provide extensive breeding material for bark beetles, and bark beetle outbreaks in spruce forests are often triggered by such events [1-8]. Bark beetle populations, especially Ips hauseri Reitter (Coleoptera: Curculionidae), began to increase in blown down Picea schrenkiana Fish. \& C.A. Mey; subsp. tienshanica Rupr. (Schrenk's spruce) [9,10]. I. hauseri is known to exhibit particularly aggressive population dynamics that enable rapid population buildup [11,12]. However, the frequency, size, and severity of past I. hauseri outbreaks in Kazakhstan are unknown. Additionally, non-native bark beetle species $I$. duplicatus L. and I. sexdentatus (Boerner), which were established in the mid- to late-1960s [9,10], were also observed in the blowdown area. The biology, ecology, and impact of these species in the Tien Shan spruce forests are unknown.

Picea schrenkiana is native to southeast Kazakhstan, Kyrgyzstan, and western China [13]. It is one of the most important tree species in Kazakhstan, of which less than 5\% is forested [14,15], and Kyrgyzstan, 
and is valued for erosion prevention, water retention, timber, and recreation. P. schrenkiana grows at elevations of 1200-3500 m a.s.l. and can attain sizes of $150 \mathrm{~cm}$ DBH and $50 \mathrm{~m}$ height (rarely, $200 \mathrm{~cm}$ and $60 \mathrm{~m}$ ). It usually grows in pure forests in Kazakhstan but is occasionally mixed with Abies sibirica Ledeb. The phylogenetic position is poorly resolved, but due to geographic isolation P. schrenkiana has few or no close relatives, having split from P. wilsonii and P. purpurea ca. $11.5 \mathrm{Ma}[13,16]$. It has relatively low genetic diversity [17] but there is some variability between isolated populations [18,19]. Ips hauseri is a primary pest of $P$. schrenkiana, its main host [11,12,20-22]. Once monophagous on P. schrenkiana, I. hauseri became a serious pest of Pinus sylvestris L., in Kyrgyzstan when P. sylvestris was introduced in the 1930s for plantation forestry [12,23]. P. sylvestris is also planted in Kazakhstan.

Cognato and Sperling (2000) [24] place I. hauseri and sister species I. duplicatus (Sahlberg) adjacent to, but not in, the clade containing I. typographus, and note that their phylogenetic placement is not well supported.

Seasonal life history depends on local temperature regimes and is usually bivoltine from 1200 to $1400 \mathrm{~m}$ a.s.1. elevation, and univoltine from 2200 to $3200 \mathrm{~m}$ a.s.1., generally overwintering as young adults under the bark and less often as larvae [11,12,22]. At lower elevations within our study area $I$. hauseri has one and a partial generation per year (observations by the second co-author). Temperature regulation of I. hauseri biology and outbreak development are not known in detail but thought to be similar to I. typographus [11,22]. At endemic population densities I. hauseri attacks dead, weakened or damaged trees. At high population densities it reportedly attacks and kills vigorous live trees as small as $5 \mathrm{~cm} \mathrm{DBH}$, and can deplete the host population over extensive areas [12,23].

Prutenskii and Romanenko (1954) [11] documented a 1940s I. hauseri outbreak in both P. schrenkiana and young plantation P. sylvestris in Kyrgyzstan. Populations increased rapidly in 1944 and 1945 after two years of drought, and collapsed rapidly when moisture levels returned to normal in 1946 and 1947. Citing Zverev (1947) [25], they reported that an outbreak occurred in our general study area at the same time, though extent and severity were not quantified. I. hauseri populations can increase rapidly or over several years and subside abruptly [11,12]. The ability of I. hauseri to cause extensive tree mortality has been compared to I. typographus, which has similar niche requirements and phenology [12]. Outbreaks are associated with drought or triggered by blowdown events [11,26]. Though identity and basic biology of native forest bark beetle species in southeast Kazakhstan are known [26], outbreak histories are unknown in any detail and it is not known how populations respond to different types and sizes of forest disturbances.

This dendrochronology study was undertaken to determine the frequency of bark beetle disturbance events in the Kazakh Tien Shan spruce forest, and secondarily to determine if disturbance history in the storm-damaged areas differed from that in undamaged areas. We used tree-ring analyses to date evidence of past disturbances in storm-damaged and -undamaged areas.

\section{Methods}

\subsection{Study Area in Southeast Kazakhstan}

Our study was conducted in the Ile Alatau National Park in the area roughly south and east of Almaty City, Kazakhstan, and north of Issyk Kul, Kyrgyzstan (Figure 1), in the Kazak portion of the region delineated by Merzlyakova (2002) [27] as Northern Tien-Shan. The Tien Shan Mountains arise abruptly from the Eurasian Steppe, reaching $7010 \mathrm{~m}$ a.s.l. elevation in Kazakhstan and $7439 \mathrm{~m}$ a.s.1. in Kyrgyzstan. The climate is extremely continental, with pronounced diurnal temperature fluctuations in both winter and summer. Due to proximity, warming from the extensive desert and dry steppe affects temperatures in the Tien Shan front ranges, especially day-time highs. Precipitation is bi-modally distributed, with approximately half received in March-June and a smaller peak in October-November. Precipitation varies from $617 \pm 132 \mathrm{~mm}$ at Almaty International Airport (675 m a.s.1., 1891-2014), to $800-1200 \mathrm{~mm} / \mathrm{yr}$ in the mountains $[28,29]$. Vegetation is zonal along the elevation gradient, with spruce and spruce-fir forests occurring above $1700 \mathrm{~m}$ a.s.l. to the tree line. 


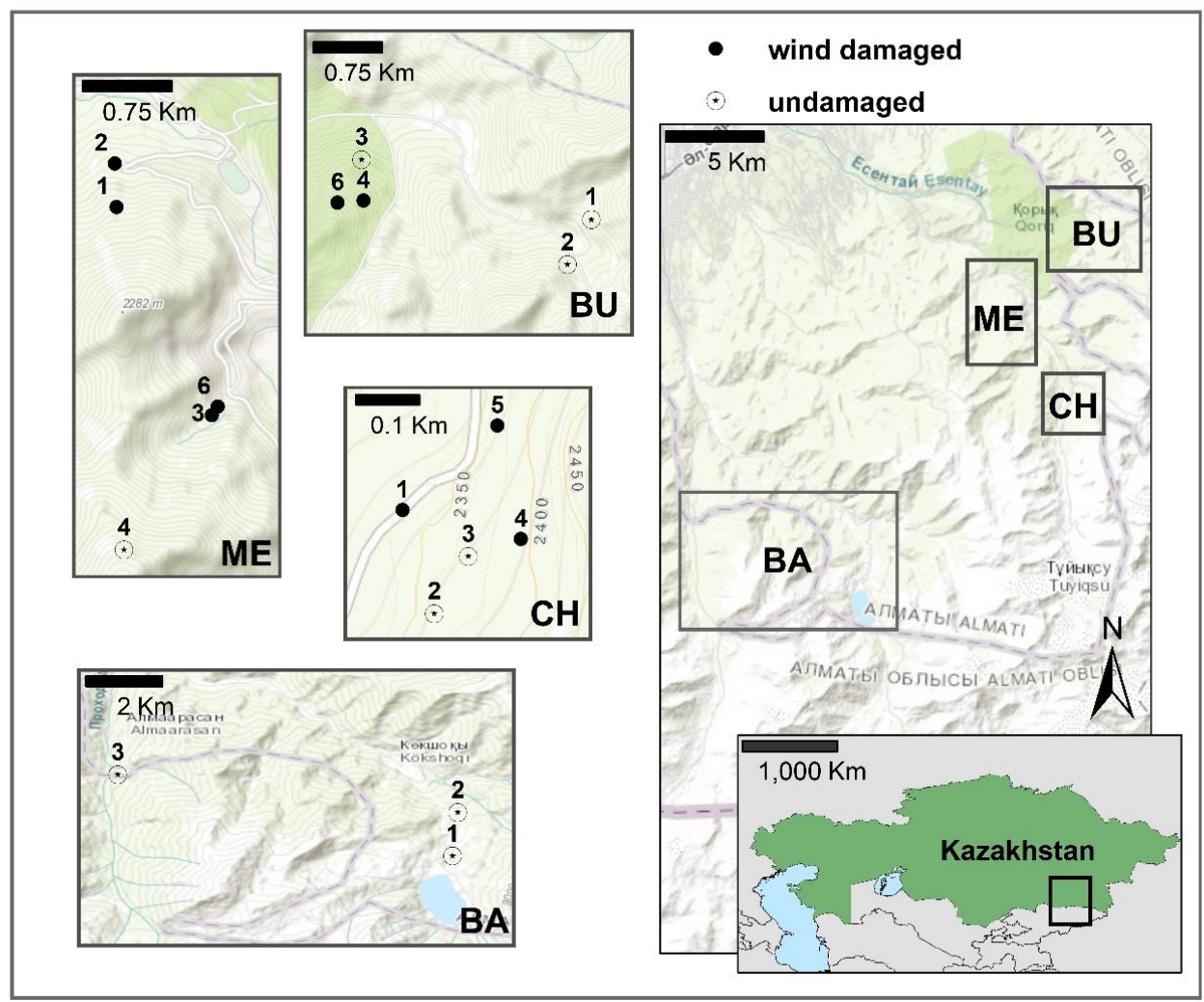

Figure 1. Study site locations in southeast Kazakhstan. Study site locations in the Tien Shan Mountains are on the right, with the inset showing the general location in Kazakhstan. Plot locations within each study area are on the left: BA1, 2 and 3 are Bolshaya Almatinka, BU1-4 and 6 are Butakovka Valley, CH1-5 are Chimbulak, and ME1-4 and 6 are Medeu Ski Valley.

The Tien Shan spruce forest is strongly dissected by avalanche and landslide chutes in many places, while in others it is fairly contiguous. Avalanches, landslides, and glacial outwash floods are relatively frequent disturbance agents. Landslides and flash floods occur with spring snow melt, but are generally largest when spring-summer precipitation coincides with glacial ice melt [30] and with glacial lake outbursts [29,31,32]. Avalanches occur during winters with heavy snowfall, especially when followed by rapid warming. Earthquakes occur with some frequency [27,33]. Fires are infrequent in the subalpine forest, occur only during extraordinarily severe weather conditions, affect small portions of the forest, and are usually human caused [28,34]. Annual area burned is associated with drought conditions and has an increasing trend for the period of record 1954-1999. The frequency and extent that avalanches, earthquakes, and fire affect spruce forest ecology in Kazakhstan are unknown. The severity of the 2011 wind events is unprecedented in living memory.

\subsection{Field and Laboratory Methods}

We collected dendrochronological material and tree inventory data in the summer of 2012 from 7 storm-damaged and 7 undamaged sites in valleys that experienced severe wind storms in 2011 (Butakovka Valley (BU), Chimbulak (CH), Medeu Ski Valley (ME)), and 3 undamaged sites in an area that did not incur storm damage (Bolshaya Almatinka (BA)) in southeast Kazakhstan (Figure 1).

We inventoried live and dead trees of 1-cm or greater DBH within a 0.04-ha circular plot for each site. Elevation, steepness (percent slope), and aspect were recorded at each plot. Stand density (trees per ha), percent mortality, average tree diameter (including live and dead trees), and quadratic mean diameter (QMD) were computed for each plot. Variability in tree size was assessed using the coefficient of variation of the mean (CVM) of tree diameter. 
Increment cores were taken from the tallied trees, other than those that could not be sampled without killing them. Where possible, two increment cores were taken from opposite sides of each tree parallel to the slope at a height $20 \mathrm{~cm}$ or less above mineral soil. Trees in storm-damaged plots were usually uprooted, often in varied directions, and sometimes found removed from their original rooted location, so it was not always possible to ascertain growth position relative to the slope and sample from the desired bole aspect. Samples from trees with butt decay were taken above the decayed portion when possible. Increment cores were not taken from small trees (destructive sampling was prohibited), nor from shattered or twisted stems in the wind-damaged areas, but the trees are included in our summarized stand descriptive statistics.

Increment cores were mounted in wooden trays and sanded with progressively finer grits until individual cell structure was observable (usually to $15 \mu$ ). Samples were cross-dated using a combination of visual pattern matching and skeleton plots [35]. On samples that did not include pith but ring curvature indicated that pith was within 10 years of the innermost ring, concentric ring pith locators were used to estimate pith dates [36]. However, frequent decay in the lower bole made age determination of the majority of trees impossible. After crossdating, ring-width measurements were recorded with J2X software on a Velmex TA system ${ }^{\circledR}$ with sensor accuracy of one $\mu \mathrm{m}$ [37]. Initial cross-dating of individual series was checked with COFECHA crossdating analysis software [38]. Samples that did not correlate with the plot-level chronology at a level of 0.3 or higher, or had ring anomalies such as branch traces, injury, or other deformation that precluded cross-dating or ring-width measurement were removed from the dendrochronology analyses [39]. When two satisfactory increment cores were obtained from the same tree, a mean ring-width was computed for each year.

\subsection{Dendrochronological Detection of Bark Beetle Outbreaks}

Bark beetle outbreaks are inferred and dated in tree-ring chronologies by growth releases in surviving trees and death dates of attacked trees [7,8,40-48]. Release of trees subjected to inter-tree competition indicate within-stand mortality or removals. Methods vary depending on whether analyses are based on site or individual tree chronologies, based on raw ring width measurements or standardized series, standardization method, whether or not the individual-tree series are scaled against its potential for release, and rule sets used to classify a growth release as outside the normal variability. Veblen et al. (1991) [40] compared different standardization approaches for detecting Dendroctonus rufipennis Kirby (Coleoptera: Curculionidae) outbreaks in P. engelmannii Parry ex Engelm. series and was able to detect growth releases better with non-standardized series. Removing trends related to tree age and geometry is more critical when dissimilar series are compared on a yearly basis (e.g., climate, defoliator host and non-host series, etc.), and where events of interest occur during juvenile tree growth, but has less utility for detecting growth releases, which by definition are substantial growth increases relative to growth in the recent past. We analyzed raw ring width series without standardization.

Within a given tree, growth releases related to stand-level disturbance are usually detected using the relative increase in the running mean of growth increment, usually constrained by limiting the minimum time between releases $[40,45,48]$. The rule set used to determine that a period of increased growth is a release outside of normal variation affects both the date assigned to inferred release initiation and the level of disturbance that the analysis can detect [48]. A disturbance is inferred when the forward 5- or 10-year running mean of the series exceeds the backward 5- or 10-year running mean by a given percent; changes on the order of 50 to $200 \%$ are commonly used. More conservative rule sets (requiring greater growth increases) detect dramatic release events that result from overstory removal, and less conservative rule sets detect stand-thinning events in addition to severe events $[48,49]$. Both the lengths of the running means and the required proportional growth increase affect the dates that inferred disturbances are associated with, requiring passage of several years before surging growth exceeds previous trends. Less conservative rule sets result in earlier release-initiation dates than 
conservative rule sets and more closely align with aerial and ground pest detection surveys [48]. Requiring a running mean of a given length can preclude automated (software-driven) detection of events at the beginning and end of the chronology.

Alternatively, releases are detected with a boundary line technique, which scales the percent growth change relative to site- and species-specific maximal growth change potential, using pre-determined boundary lines for individual species [42,43]. There are similar matters related to the magnitude and duration of growth changes required for releases to be inferred as disturbance events, and establishing the boundary lines requires large data sets collected from multiple sites, tree ages, and tree sizes. This method is applicable in mixed-species and mixed-age forests where different trees have drastically different release potential, i.e., canopy and sub-canopy trees may respond differently to stand-opening events, or some species are not responsive to such events. Our study design is not suited to establishing the boundary lines, our sample size is marginal for that purpose, and we were precluded from sampling small trees.

Site-level disturbances are usually inferred using thresholds such as at least 2 trees recording growth release over a five-year period. Widespread or regional outbreaks are usually inferred when $25 \%$ (or higher threshold) of sites record disturbances within a five-year period. These thresholds filter out release events at different levels.

Our criteria for growth releases was applied to individual spruce trees, and computed with Microsoft Excel 2013, as follows:

1. A growth release was determined to have occurred when the 10-year running mean of ring widths increased by $50 \%$ or more and growth was sustained above the pre-release level for 10 or more years, with single-year deviations permitted.

2. The initial year of the growth release was dated as the first year in which the growth increment exceeded the previous 10 -year mean by $50 \%$. Thus, each event was detected using the running mean, but dated with respect to the first year of the sustained growth increase.

3. The final year of the growth release was defined as the year prior to the year in which growth returned to the pre-release rate (i.e., the last year of elevated growth). Two types of releases were included as dated events but excluded from release-duration computations: (a) Growth of released trees sometimes plateaued, without declining, at a rate higher than the pre-release average, which occurs when released suppressed trees reach better canopy positions, or when the disturbance occurs near the end of the chronology; (b) Individual trees occasionally incurred multiple releases, with later releases occurring before growth stabilized from the initial release.

4. A minimum time of 15 years between initial release years was used to distinguish discrete events.

Tree-level growth releases were composited by site, and site-level events were identified as those in which 2 or more trees per site initiated a growth release within a 5-yr period. Landscape-scale events were identified as those in which $25 \%$ or more of sites recorded releases over a 5 -yr period. We also analyzed all detected releases without filtering the analyses by the events detected on a specified number or proportion of trees or sites affected.

\subsection{Statistical Comparisons}

Temporal patterns of growth releases were compared within and between plots for all sampled sites as well as between wind- and non-wind-damaged sites. Release frequency was computed for each site for 1930-1965 and 1966-2012 (an a posteriori classification that we discuss later), covering the period common to all sites. Mean site, stand, and growth release frequency of wind-damaged and non-damaged groups were compared using two-tailed $t$-tests for independent samples, and associations between growth release frequency and site and plot characteristics were measured using Pearson's correlation coefficient. Growth release frequencies for different time periods were compared with paired $t$-tests. Comparisons were completed using SPSS Release 18.0.0 [50]. 
Debris-flow, avalanches, and earthquake disturbances manifest in tree-ring series of surviving trees as abrupt, usually short, declines in radial growth $[29,33]$ and are unlikely to be confused with bark beetle-related disturbance. We did not find evidence of such events in our samples, presumably because we minimized sampling near forest edges.

\section{Results}

Usable dendrochronology samples were collected from 219 P. schrenkiana. Samples from Crataegus, Sorbus, and Salix were not used in the analysis because they were either very young or did not correlate well with the spruce series. Average chronology length was 151 years, varying from 96 to 262 years (Table 1). The chronology lengths underestimate stand age (or the age of the oldest tree in mixed-age stands), often substantially, because of the prevalence of stem decay. Absent rings were observed on $8.45 \%$ of cores, or $0.153 \%$ of measured rings. Site mean inter-series correlations were $0.537 \pm 0.079$. Trees greater than 120 years old were present at all sites but one (Table 1). The age at which susceptibility to I. hauseri increases is unknown, but 120 is the age at which susceptibility to I. typographus increases considerably in Norway spruce, P. abies (L.) Karst [2]. 
Table 1. Site and chronology descriptive variables, and growth release frequencies for sites with and without wind damage from the 2011 storms.

\begin{tabular}{|c|c|c|c|c|c|c|c|c|c|c|c|c|c|}
\hline \multirow{2}{*}{ Plot } & \multirow{2}{*}{$\begin{array}{l}\text { Innermost } \\
\text { Ring Date }\end{array}$} & \multirow{2}{*}{ RBAR } & \multirow{2}{*}{$\begin{array}{c}\text { Mean } \\
\text { dbh }(\mathrm{cm})\end{array}$} & \multirow{2}{*}{$\begin{array}{l}\text { CVM } \\
\text { (dbh) }\end{array}$} & \multirow{2}{*}{$\begin{array}{l}\text { QMD } \\
\text { (cm) }\end{array}$} & \multirow{2}{*}{ Elev. (m) } & \multirow{2}{*}{$\begin{array}{c}\text { Slope } \\
(\%)\end{array}$} & \multirow{2}{*}{$\begin{array}{l}\text { Aspect } \\
\text { (Degrees) }\end{array}$} & \multirow{2}{*}{$\begin{array}{c}\text { Mortality } \\
(\%)\end{array}$} & \multirow{2}{*}{$\begin{array}{c}\text { Density } \\
\text { (tph) }\end{array}$} & \multicolumn{3}{|c|}{ Release Frequency } \\
\hline & & & & & & & & & & & 1930-1965 & $>1965$ & Combined \\
\hline \multicolumn{14}{|c|}{ No damage in 2011 storms } \\
\hline BA1 & 1863 & 0.473 & 32.0 & 78.9 & 40.1 & 2471 & 9 & 326 & 15.4 & 260 & 0.029 & 0.114 & 0.077 \\
\hline BA2 & 1750 & 0.607 & 26.5 & 62.1 & 30.9 & 2342 & 18 & 8 & 15.0 & 400 & 0.143 & 0.143 & 0.143 \\
\hline BA3 & 1843 & 0.422 & 27.2 & 94.1 & 36.8 & 2389 & 2 & 326 & 17.6 & 340 & 0.114 & 0.114 & 0.114 \\
\hline BU1 & 1879 & 0.600 & 52.0 & 48.6 & 57.3 & 2016 & 54 & 272 & 8.3 & 240 & 0.000 & 0.029 & 0.016 \\
\hline BU2 & 1872 & 0.563 & 32.7 & 71.4 & 39.4 & 2082 & 48 & 88 & 0.0 & 200 & 0.029 & 0.114 & 0.077 \\
\hline BU3 & 1868 & 0.431 & 85.8 & 66.9 & 101.6 & 1843 & 70 & 55 & 0.0 & $\mathrm{n} / \mathrm{a}$ & 0.029 & 0.029 & 0.029 \\
\hline $\mathrm{CH} 2$ & 1873 & 0.458 & 32.5 & 83.2 & 41.1 & 2392 & 36 & 270 & 12.5 & 160 & 0.057 & 0.086 & 0.073 \\
\hline $\mathrm{CH} 3$ & 1916 & 0.431 & 20.3 & 113.6 & 30.3 & 2388 & $\mathrm{n} / \mathrm{a}$ & 0 & 4.5 & 440 & 0.000 & 0.086 & 0.049 \\
\hline ME2 & 1865 & 0.590 & 34.4 & 33.4 & 36.1 & 1739 & 33 & 97 & 19.2 & 520 & 0.143 & 0.171 & 0.159 \\
\hline ME4 & 1857 & 0.612 & 42.8 & 46.9 & 46.5 & 2387 & 46 & 42 & 7.1 & 280 & 0.057 & 0.057 & 0.057 \\
\hline mean & & 0.519 & 38.6 & \# 69.9 & 46.0 & 2205 & 35.1 & & \#\# 10.0 & \# 316 & ${ }^{*} 0.060$ & * 0.094 & 0.079 \\
\hline StDev & & 0.082 & 18.8 & 23.9 & 21.0 & 263 & 22.2 & & 7.0 & 119 & 0.055 & 0.047 & 0.047 \\
\hline \multicolumn{14}{|c|}{ Damaged in 2011 storms } \\
\hline BU4 & 1877 & 0.552 & 35.9 & 46.5 & 39.3 & 1943 & 26 & 22 & 45.5 & 220 & 0.057 & 0.143 & 0.106 \\
\hline BU6 & 1894 & 0.558 & 42.0 & 41.1 & 45.1 & 2029 & 32 & 328 & 80.0 & 200 & 0.057 & 0.086 & 0.073 \\
\hline $\mathrm{CH} 4$ & 1853 & 0.607 & 49.5 & 44.6 & 53.9 & 2362 & 40 & 250 & 71.4 & 280 & 0.029 & 0.229 & 0.142 \\
\hline CH5 & 1818 & 0.584 & 53.1 & 23.5 & 54.4 & 2400 & 28 & 278 & 100.0 & 300 & 0.086 & 0.171 & 0.134 \\
\hline ME1 & 1863 & 0.671 & 46.9 & 63.3 & 54.7 & 1873 & 28 & 38 & 72.7 & 220 & 0.029 & 0.086 & 0.061 \\
\hline ME3 & 1869 & 0.532 & 25.9 & 70.2 & 31.3 & 1959 & 36 & 320 & 58.3 & 240 & 0.029 & 0.029 & 0.029 \\
\hline ME6 & 1884 & 0.438 & 45.1 & 71.6 & 53.9 & 1938 & 38 & 282 & 28.6 & 140 & 0.000 & 0.029 & 0.016 \\
\hline mean & & 0.563 & 42.6 & \# 51.5 & 47.5 & 2072 & 32.6 & & \#\# 65.2 & \# 229 & ${ }^{*} 0.041$ & * 0.110 & 0.080 \\
\hline StDev & & 0.072 & 9.2 & 17.6 & 9.3 & 216 & 5.5 & & 23.5 & 53 & 0.028 & 0.074 & 0.049 \\
\hline \multicolumn{14}{|c|}{ All plots combined } \\
\hline mean & & 0.537 & 40.3 & 62.3 & 46.6 & 2150 & 34.0 & & 32.7 & 278 & $* * 0.052$ & ** 0.101 & 0.080 \\
\hline StDev & & 0.079 & 15.3 & 22.9 & 16.8 & 247 & 16.6 & & 31.9 & 103 & 0.045 & 0.058 & 0.046 \\
\hline
\end{tabular}

RBAR is the chronology interseries correlation. The innermost ring date provides chronology length, but should not be used to infer stand age because short chronologies are produced from old trees with stem decay. Means in the same column preceded by one or two pound signs (\# and \#\#) are significantly different at 0.1 and 0.01 with a two-tailed t-test. Rows preceded by * and ** are significantly different at 0.05 and 0.01 , respectively, with a paired $t$-test. 


\subsection{Disturbance Events}

Growth releases were detected on all sites, but incidence was low and varied considerably (Table 1). We detected 112 growth releases, averaging 0.49 per tree, though chronology length varied considerably by tree. Overall, $0.44 \%$ of measured rings were determined to be the initial year of a growth release (1 in 227 rings).

Events for which 2 or more trees on the same plot incurred a growth release within a 5-yr period were asynchronous and exceptionally infrequent (Figure 2). Only 17 events were detected, and the $25 \%$ filter indicating a large-scale event was never met, excluding an early event when sample size was low. Almost half of the events $(47 \%)$ occurred in the last 60 years.

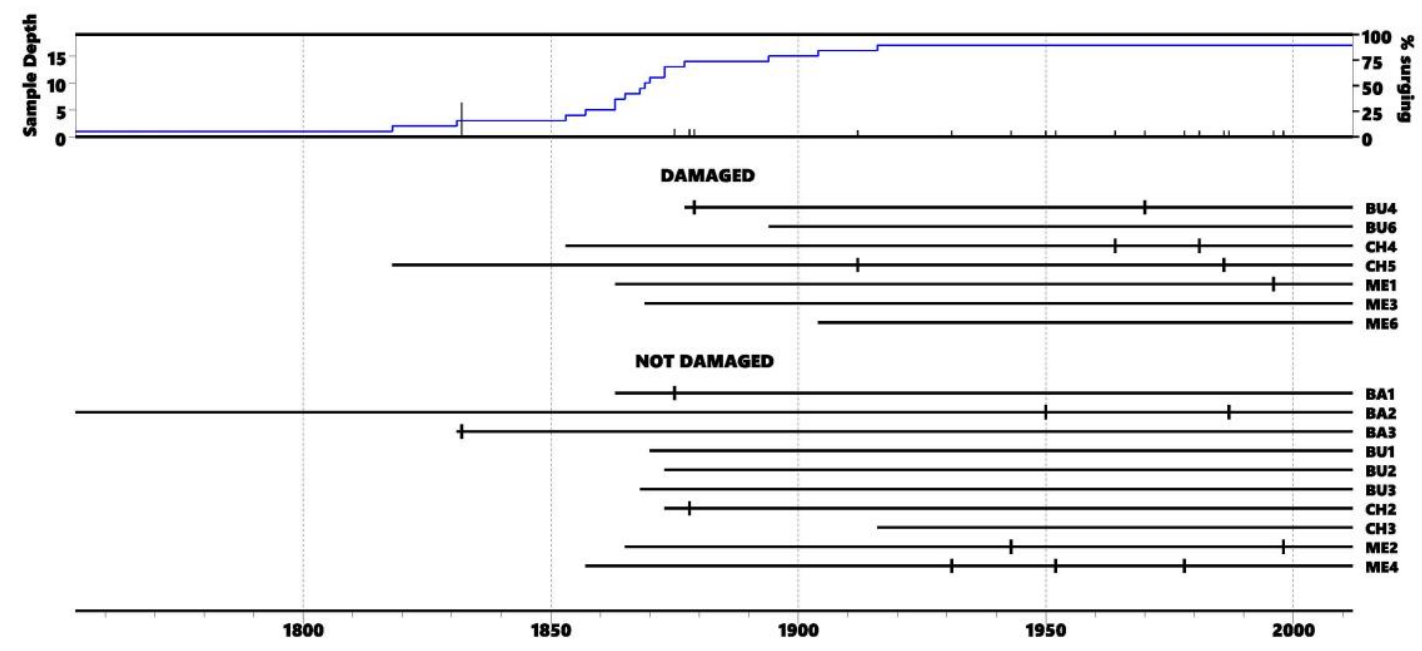

Figure 2. Site-level reconstruction of releases in storm-damaged and -undamaged Picea schrenkiana stands in southeast Kazakhstan. The bottom chart records events in which growth releases initiated in 2 or more trees on a given plot within a 5-yr period. The top chart records the number of plots in the chronology at any given time (blue) and the percent of plots recording the growth release (histogram, composited from the bottom chart). BA is Bolshaya Almatinka, BU is Butakovka Valley, $\mathrm{CH}$ is Chimbulak, and ME is Medeu Ski Valley.

Unfiltered growth releases (single trees per plot) were also infrequent (Figure 3, Table 1). Tree events were also asynchronous, seldom affecting $25 \%$ or more of sites. Growth releases occurred on most sites in the late 1920s, and in the 1930s if not in the 1920s, and again in most sites in the 1980s, especially the early 1980s (Figures 2 and 3). Though releases occurred more frequently during these periods, they were not synchronous.

There was a trend of increasing single-tree growth release frequency with time (Figure 3, Table 1). This trend was consistent throughout the reconstruction, though there were insufficient numbers of trees in the chronologies to draw conclusions prior to 1910. Release frequency increased beginning approximately the mid-1960s, almost doubling in the 35 years after 1965 compared to the 35-year period ending in 1965, from one release in 19.2 years to one in 9.9 years (Table 1). Please note that these are tree- and plot-level releases, not extensive disturbance events.

Within sites, individual-tree growth releases occurred in single years (occasionally 2 adjacent years) rather than over several contiguous years, with little or no temporal clustering at the site level. Occasionally, different trees on the same site incurred releases over several years (e.g., CH4 and BA2 in Figure 3). This may result from emerging bark beetles attacking nearby trees in consecutive years such that mortality at a given location occurred over several years, typical of spot expansion observed with other bark beetle species [51]. 


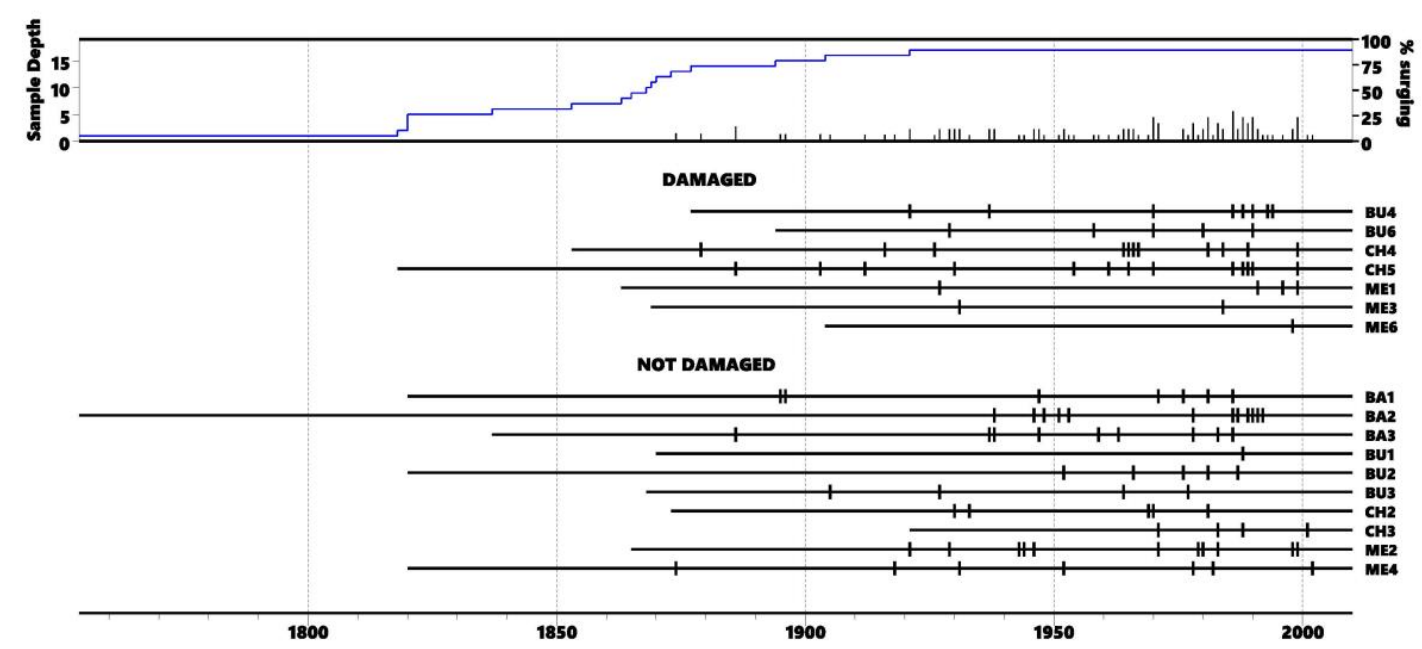

Figure 3. Tree-ring reconstruction of single-tree releases in storm-damaged and -undamaged Picea schrenkiana stands in southeast Kazakhstan. The chart records events in which a growth release initiated in a single tree in a single year on a 0.04-ha plot, by site, with each tick mark representing a growth release of at least $50 \%$ lasting 10 or more years. BA is Bolshaya Almatinka, BU is Butakovka Valley, $\mathrm{CH}$ is Chimbulak, and ME is Medeu Ski Valley.

Computed as an average of all detected releases, regardless of tree or site, releases lasted $27.4 \pm 15.1$ years, based on 60 tree-level events for which duration could be estimated. The magnitude of change in growth rate for individual releases was usually between 200 and $400 \%$, rarely below $100 \%$, and sometimes as high as $1200 \%$.

Single-tree growth release frequency was associated with greater stand density and less steepness both before and after 1965 (Table 2) (stand density and steepness were not significantly correlated with each other $(r=-0.32$, sig. $=0.25))$. Comparisons of release frequency and temporal patterns by stand age are precluded by the incidence stem decay, which produces short series from older trees, and other sampling challenges.

Table 2. Pearson correlation coefficient $(r)$ between plot variables and the frequency of growth releases before and after 1965, as well as 1930-2012.

\begin{tabular}{|c|c|c|c|c|c|c|}
\hline & \multicolumn{2}{|c|}{ 1930-1965 } & \multicolumn{2}{|c|}{ after 1965} & \multicolumn{2}{|c|}{ Combined } \\
\hline & $r$ & sig. & $r$ & sig. & $r$ & sig. \\
\hline mean DBH & -0.247 & 0.340 & -0.223 & 0.390 & -0.243 & 0.347 \\
\hline $\mathrm{CVM}(\mathrm{DBH})$ & -0.306 & 0.232 & -0.359 & 0.158 & -0.384 & 0.128 \\
\hline QMD & -0.315 & 0.218 & -0.285 & 0.266 & -0.339 & 0.184 \\
\hline elevation & 0.094 & 0.719 & 0.309 & 0.228 & 0.259 & 0.315 \\
\hline slope & -0.501 & 0.048 & -0.416 & 0.109 & -0.507 & 0.045 \\
\hline stand density & 0.579 & 0.017 & 0.430 & 0.096 & 0.560 & 0.024 \\
\hline mortality & 0.045 & 0.865 & 0.364 & 0.151 & 0.276 & 0.283 \\
\hline $\begin{array}{l}\text { growth release frequency } \\
\text { after } 1965\end{array}$ & 0.513 & 0.035 & & & & \\
\hline
\end{tabular}

Though not a study objective, we found no evidence of defoliator outbreaks in the spruce series. Defoliation leaves a signature of suppressed radial growth in tree-ring chronologies that can be used to dendrochronologically reconstruct defoliator outbreak regimes [52], but no such evidence was found in our series at any scale.

\subsection{Storm Damage}

Wind-damaged and non-damaged sites are similar with respect to average tree size, elevation, steepness, and aspect (Table 1). On average, stand density was lower and tree diameter more uniform 
on wind-damaged sites compared with trees on non-damaged sites. Though wind-damaged and non-damaged sites had, on average, similar numbers of disturbances since 1965, two damaged sites in Medeu Valley had incurred unusually low numbers of disturbances prior to 2011 (Figures 2 and 3). Releases were not detected in the years just prior to the storms, indicating that storm damage was not influenced by prior mortality events. Mortality in 2012 was $65 \%$ on wind-damaged sites, but this underestimates the complete impact of the storms, as damaged trees were still dying from physical storm damage (partially pushed over, broken, or missing significant portions of the crown) at the time of sampling.

\section{Discussion}

We reconstructed a nearly 200-year history of disturbances in the Tien Shan spruce forest and found no evidence of either extensive high-severity bark beetle outbreaks or synchronous stand thinning events within that time frame. Growth releases were local in scale, and only weakly temporally coincidental on several plots during two periods.

Collectively, the evidence indicates that the primary biological disturbance agent in the Tien Shan spruce forest has historically functioned at a local scale. There is no evidence of extensive bark beetle outbreaks in our 200-year reconstruction. Furthermore, the evidence indicates that extensive high-severity bark beetle outbreaks such as occur in spruce forests in western Europe, Russia, and North America, primarily by I. typographus and D. rufipennis, are not typical in the Kazakh portion of the Tien Shan. Direct comparisons between studies are difficult, but Čada et al. (2013) [7] and Janda et al. (2014) [47] detected three extensive high-severity I. typographus and/or wind events plus an ongoing event in the last 300 years in P. abies forests in the Bohemian Forest. D. rufipennis incurs extensive outbreaks on average $1-4$ times per century across much of its range $[45,46,48,53,54]$. None of the 17 plot-level events in our data occurred concurrently. Extensive, severe outbreaks by native bark beetle species are also not reported from spruce forests in central and western Asia [55-57].

Even plot-level events (Figure 3) occur considerably less frequently than was observed with $I$. typographus and D. rufipennis [7,40,41,44-46,48]. Čada et al. (2013) [7] reported extensive but less severe events every 10-50 years for I. typographus. Counting prolonged periods as single events, in the most recently reconstructed 100-yr period, 60 D. rufipennis events occurred on 23 sites on the Kenai Peninsula, Alaska [45], and almost 600 on 34 sites in Arizona [48]. Our data show only 17 events on 17 sites, and never came close to the $25 \%$ threshold needed to detect an extensive outbreak. If individual years were counted, rather than counting prolonged period as single events, the difference would increase by at least one order of magnitude.

In our study, disturbance frequency is associated with greater stand density and less steepness both before and after 1965, and weakly after 1965 with greater uniformity in tree size. High stand density is a common risk factor for coniferous bark beetles, and uniform tree size may reflect even-aged stands reaching a susceptible stocking or tree size threshold, though our data are not suited to teasing out interacting effects of tree size, stocking, age structure, and topographic factors as they relate to bark beetle susceptibility.

\subsection{Doubling of Disturbance Frequency ca. 1965}

Though disturbance frequency is low throughout the record and is related to local (stand-level) rather than landscape-scale outbreaks, it doubled after about the mid-1960s (Table 1, Figures 2 and 3). Factors that may have contributed to increased bark beetle activity after about 1965 include establishment of non-native bark beetle species and warmer temperatures. Tree species composition is about $95 \%$ spruce, so variability in host dominance and species composition are not relevant factors in the study area. 


\subsubsection{Non-Native Bark Beetles}

Exotic bark beetles, including I. duplicatus and I. sexdentatus, established locally in the 1960s when raw logs were imported from Siberia and northern Kazakhstan during construction of railroads and the Medeu Mudflow Control Dam, and/or when European-grown spruce and pine were planted in the wildland-urban interface after completion of the dam $[10,58]$. The control dam protects the city of Almaty and the Medeu winter sports complex from avalanches and mud and debris flows. At $1750 \mathrm{~m}$ a.s.l., the control dam is located just within the lower elevation zone for P. schrenkiana, and close to P. sylvestris plantations. Areas below the dam became attractive for urban development, and European-grown trees of a variety of species are commonly planted in the new wildland-urban interface with little regard to the importation of exotic pests $[10,58]$. However, importation of raw bark-on logs used in construction is the more likely source of exotic bark beetle species because urban planting stock tends to be smaller than sizes typically attacked by these bark beetles.

Pheromone-trap monitoring shows that I. duplicatus and I. sexdentatus are established in the study area $[9,10]$, but the overwhelming majority of Ips are hauseri $[9,10]$. Sagitov et al. (2016) [10] caught significant numbers of $I$. hauseri and small numbers of I. duplicatus in monitoring traps baited for $I$. typographus (synthetic lures for I. typographus are known to be attractive to I. duplicatus $[59,60]$ and vice-versa [61,62]). The hauseri beetles were originally reported as typographus, but were later identified by M.Yu. Mandelshtam as hauseri. Later sampling by this group also caught I. sexdentatus. Kazenas et al. (2016) [58] caught I. hauseri and I. sexdentatus (pheromone lures were not specified). Increased disturbance frequency, even at a small local scale, might be related to establishment of exotic species. However, because few duplicatus or sexdentatus have been observed in the blowdown area we do not think that exotics are responsible for the post-1960 increase in disturbance frequency.

\subsubsection{Warming Climate}

There has been a generally increasing trend in temperature and a decreasing trend in precipitation across Kazakhstan since 1895 [28,29,63]. The annual frequency of frost days has decreased about 20 days since 1946 in Almaty Oblast, and heat waves have become more frequent, longer, and more intense [64]. Changes in tree growth response to climate occurred in the next lower vegetation zone ca. 1970, with increasing sensitivity to spring precipitation [65]. I. hauseri outbreaks are known to be associated with drought $[11,12]$. Outbreaks of other spruce-attacking bark beetles, especially $I$. typographus and D. rufipennis, are associated primarily with warmer-than-usual periods, with drought being a secondary factor $[2,45,48,66,67]$. Warmer temperatures can change beetle development rates, voltinism, overwintering survivorship, and emergence synchrony, and enable emergence when tree defenses are low, with different factors coming into play for different insect-host systems, seasons, and thresholds. Any of these factors can alter bark beetle-related disturbance frequency.

Beetle trap catches after the windstorms peaked in 2015 and declined after 2015, possibly due to exceptionally wet conditions in 2016. Spruce mortality from I. typographus peaks in the 3rd year after storm disturbance $[1,5,68]$. Spring 2016 precipitation in Almaty Oblast was in the highest 10th percentile since 1940 [64]. Spring moisture shortens the montane growing season in the Ile Alatau due to snow insulation and/or cold rains cooling the soil $[65,69]$. Drought-responsive multi-voltine bark beetles, particularly Ips, often respond rapidly to drought, and terminate abruptly with a shift to wetter conditions [2].

\subsection{Outbreak Potential}

A relevant question is: why did the storms not trigger an I. hauseri outbreak? I. hauseri and I. typographus supposedly fill similar niches, and I. hauseri is thought to be as aggressive as $I$. typographus [12], weather conditions were suitable, and considerable host material (damaged and not damaged) was available, so an outbreak might be expected to occur. Managers undertook aggressive salvage operations, in part to remediate the risk of a bark beetle outbreak, but much of 
the storm-damaged forest was inaccessible. Bark beetles attacked trees within and adjacent to the storm-damaged area, with some spot growth, but an extensive outbreak did not develop. Weather conditions after the windstorm were conducive to increasing bark beetle populations, but suitable conditions did not persist. The 2012 spring was within 10\% of the driest seasons on record, with precipitation at $40-60 \%$ of normal, and spring and summer were exceptionally warm [70]. However, spring precipitation in 2016 was in the highest 10th percentile since 1940 [64], and the bark beetle populations declined immediately. Results of our study indicate that extensive severe outbreaks have not occurred in the last 200 years. Collectively, our results and the failure of a post-storm outbreak to continue after moisture returned to normal suggest that persistent drought is necessary to sustain $I$. hauseri outbreaks. Additionally, either I. hauseri is not as aggressive as I. typographus, or year-to-year variation in the Tien Shan weather prevents outbreak development, as there is no evidence of extensive stand-thinning or high-severity outbreaks such as occur with I. typographus in its natural range.

\subsection{Reconstruction Limitations}

The growth releases detected in this study cannot be unequivocally attributed to bark beetle-related tree mortality. It is standard practice in dendroentomology to confirm that some inferred outbreaks reflect documented events [71]. That is not possible here, because the detected activity is so minor and there are few records. Our reconstruction does show a disturbance in Chimbulak (at $\mathrm{CH} 4$ ) corresponding to a drought-associated outbreak in 1945 and 1946 in the same general area reported by Pruntenskii and Romaneko (1954) [9] (citing Zverev (1947) [25]), though they did not indicate either extent or severity. The reverse does appear to be true-neither our reconstruction nor local knowledge indicate that outbreaks occurred in the recent past. There are few records documenting forest pest activity in the Kazakh Tien Shan Mountains, especially any that quantify extent and severity. Though quantitative records are lacking, it is logical to assume that Ismukhambetov (1976) [26] would have noted recent extensive severe outbreaks. Likewise, local experts, including co-authors and forest managers, recall no extensive or severe outbreaks. Therefore, our reconstruction is consistent with local knowledge of bark beetle activity. Furthermore, our data indicate low levels of disturbance, so any erroneous attribution of disturbance agent would indicate an even lower level of bark beetle disturbance than what we infer. The reconstruction reflects small spatially and temporally isolated disturbances, with only two periods of increased disturbance levels across multiple sites, and very few sustained periods of disturbance at the site level.

Additionally, during release, only 1 to a few trees show synchronous releases, but radial growth increased considerably (200-400\%). This reflects small-scale disturbances that killed individual large overstory trees, creating canopy gaps that provide growing space and resources for newly released understory trees, rather than watershed- or landscape-scale mortality events. The most reasonable explanation is that of bark beetles occasionally killing large, declining, injured, or diseased trees, thereby releasing understory trees from suppression. It is likely that the majority of the growth releases observed over the 200-year period reflect endemic levels of bark beetle activity that occasionally reach incipient outbreak levels. Chronology lengths from our plots are not a good indicator of stand age because of the high incidence of stem decay-some of the shortest series were from the oldest-appearing, but hollow trees. Our oldest dated inner ring was 1750, but Panyushkina et al. (2018) [72] and Zhang et al. (2017) [73] sampled trees dating in the early 1700s near the upper tree-line and the lower spruce zone, respectively. During work to support Panyushkina et al. (2018) [72], we sampled several trees dating to between 1702 and the 1750s, and one to 1579. Both upper and lower forest zones were influenced by agriculture, grazing, and harvesting, but the majority of the spruce zone is too steep to have been utilized for those purposes in the past. More extensive sampling would provide information about forest age, demographics and successional patterns. Our study does not provide information regarding the role that stem and root pathogens may play in these patterns, but we think that role is significant. 


\section{Conclusions}

Ips hauseri is the most important bark beetle on P. schrenkiana in southeast Kazakhstan, but its biology, ecology, and outbreak dynamics are poorly known. Seasonal life history depends on temperature and is univoltine at high elevations but bivoltine in lower, warmer environments. The ability of I. hauseri to cause extensive tree mortality has been compared to I. typographus, which has similar niche requirements and phenology $[11,12,22]$. Outbreaks are associated with drought or triggered by blowdown events $[11,26]$. However, frequency, extent, and severity of outbreaks are unknown.

We dendrochronologically reconstructed a nearly 200-year history of forest disturbances in the Kazakh Tien Shan Mountains and found no evidence of extensive high-severity bark beetle outbreaks or even of synchronous stand-thinning events within that time frame. Growth releases were local in scale, consistent with small-scale disturbances that killed individual large overstory trees. These results, combined with failure of an outbreak to fully develop after blowdown events in 2011 indicate that prolonged drought may be necessary to sustain I. hauseri outbreaks, or that year-to-year variation in the Tien Shan weather prevents outbreak development. I. hauseri is probably less aggressive than I. typographus, at least on their natural hosts within their natural ranges. The evidence indicates that the primary biological disturbance agent in the Tien Shan spruce forest has historically functioned at a local scale and that extensive high-severity bark beetle outbreaks such as occur in spruce forests in western Europe, Russia, and North America, primarily by I. typographus and D. rufipennis, are not typical in the Kazakh portion of the Tien Shan. Though disturbance frequency was very low throughout the reconstructed period, it doubled after about 1964, probably due to warming climate.

Tree-ring reconstructions from spruce forests $[7,40,45-48,53,54]$ are typically longer than our Tien Shan reconstruction. Rather than reflecting a relatively young forest age, our reconstruction is short due to the prevalence of stem decay in older trees, which results in short chronologies from old trees.

Author Contributions: All authors contributed to study conception, design, data interpretation, and manuscript revisions. I.P.P. supervised laboratory cross-dating and ring-width measurements. A.M.L. completed the analyses and prepared the first and final drafts. Project administration and funding acquisition were completed by A.O.S. and I.P.P.

Funding: The research was supported by FST Nos. 055 and 309 Award of the Science Committee of Ministry of Education and Science, Republic of Kazakhstan, for the development of new biological products for control of spruce bark beetle populations, and NSF BCS-Archaeology and Archaeometry \#1122359.

Acknowledgments: Our paper is dedicated to the memory of co-author Nursagem Ashikbaev, a naturalist of the first order who sadly passed away in July 2019. We are thankful for field assistance and support from Bakit Kushtanov and Gulnaz Mengdbayeva with the Kazakh Research Institute of Plant Protection and Quarantine, and the administrators and foresters with the Ile-Alatau National Park and the Almaty National Park. Thanks also to Kelley J. Clark, Laboratory of Tree-Ring Research, the University of Arizona, for assistance with the tree-ring measurements.

Conflicts of Interest: The authors declare that they have no conflicts of interest. This article was written and prepared by U.S. Government employees on official time and it is, therefore, in the public domain and not subject to copyright.

\section{References}

1. Bakke, A. The recent Ips typographus outbreak in Norway: Experiences from a control program. Holarct. Ecol. 1980, 12, 515-519. [CrossRef]

2. Christiansen, E.; Bakke, A. The spruce bark beetle of Eurasia. In Dynamics of Forest Insect Populations: Patterns, Causes, Implications; Berryman, A.A., Ed.; Plenum: New York, NY, USA, 1988; pp. 479-503.

3. Inouye, M. Details of bark beetle control in the storm-swept areas in the natural forest of Hokkaido, Japan. Z. Angew. Entomol. 1963, 51, 160-164. [CrossRef]

4. Marini, L.; Økland, B.; Jönsson, A.M.; Bentz, B.; Carroll, A.; Forster, B.; Grégoire, J.C.; Hurling, R.; Nageleisen, L.M.; Netherer, S.; et al. Climate drivers of bark beetle outbreak dynamics in Norway spruce forests. Ecography 2016, 40, 1426-1435. [CrossRef] 
5. Schroeder, L.M.; Lindelöw, Å. Attacks on living spruce trees by the bark beetle Ips typographus (Col. Scolytidae) following a storm-felling: A comparison between stands with and without removal of wind-felled trees. Agric. For. Entomol. 2002, 4, 47-56. [CrossRef]

6. Vega, F.E.; Hofstetter, R.W. Bark Beetles: Biology and Ecology of Native and Invasive Species; Academic Press: London, UK, 2015.

7. Čada, V.; Svoboda, M.; Janda, P. Dendrochronological reconstruction of the disturbance history and past development of the mountain Norway spruce in the Bohemian Forest, central Europe. For. Ecol. Manag. 2013, 295, 59-68. [CrossRef]

8. Janda, P.; Trotsiuk, V.; Mikolás, M.; Bače, R.; Nagel, T.A.; Seidl, R.; Seedre, M.; Morrissey, R.C.; Kucbel, S.; Jaloviar, P.; et al. The historical disturbance regime of mountain Norway spruce forests in the Western Carpathians and its influence on current forest structure and composition. For. Ecol. Manag. 2017, 388, 67-78. [CrossRef]

9. Kadyrbekov, R.K.; Tleppaeva, A.M. Species composition of xylophagous insects (Insecta, Coleoptera, Hymenoptera) on a forest windfall in the Almatinka Little River gorge (Ile Alatau Range, Northern Tien Shan). Bull. Kazakh Natl. Univ. Biol. Ser. 2014, 2, 61-67. (In Russian)

10. Sagitov, A.; Mukhamadiev, N.; Ashikbaev, N.; Mazarzhanova, K.; Bolat, Z.; Mendibaeva, G.; Abzhanbayev, D. Pheromone traps application against bark beetles (Coleoptera: Scolytidae) in Ili-Alatau Mountains. Kast. Univ. J. Eng. Sci. 2016, 2, 14-20.

11. Prutenskii, D.I.; Romanenko, K.E. Ips hauseri: Its role and importance in the mortality of Schrenks spruce and pine in Kyrgyzstan. In Proceedings of the Institute of Botany \& Plant Industry; The Academy of Sciences, USSR Kyrgyzstan Branch: Frunze, Russia, 1954; Volume 1, pp. 177-191. (In Russian)

12. EPPO. Ips Hauseri. Data Sheets on Quarantine Pests; European and Mediterranean Plant Protection Organization: Paris, France, 2005; p. 3. [CrossRef]

13. Lockwood, J.D.; Aleksić, J.M.; Zou, J.; Wang, J.; Liu, J.; Renner, S.S. A new phylogeny for the genus Picea from plastid, mitochondrial, and nuclear sequences. Mol. Phylogenet. Evol. 2013, 69, 71-727. [CrossRef]

14. Chemonics. Biodiversity Assessment for Kazakhstan; Task Order under the Biodiversity \& Sustainable Forestry IQC (BIOFOR); USAID Central Asian Republics Mission: Almaty, Kazakhstan, 2001; p. 64.

15. Mambetov, B.T.; Maisupova, B.D.; Utebekova, A.D.; Dosmanbetov, D.A.; Kelgenbaev, N.S.; Dukenov, Z.S. Modern forestry in Kazakhstan. Int. J. Eng. Sci. Humanit. 2013, 3, 1-8.

16. Ran, J.-H.; Shen, T.-T.; Liu, W.-J.; Wang, P.-P.; Wang, X.-Q. Mitochondrial introgression and complex biogeographic history of the genus Picea. Mol. Phylogenet. Evol. 2015, 93, 63-76. [CrossRef] [PubMed]

17. Li, Y.; Stocks, M.; Hemmilä, S.; Källman, T.; Zhu, H.T.; Zhou, Y.F.; Chen, J.; Liu, J.Q.; Lascoux, M. Demographic histories of four spruce (Picea) species of the Qinghai-Tibetan Plateau and neighboring areas inferred from multiple nuclear loci. Mol. Biol. Evol. 2010, 27, 1001-1014. [CrossRef] [PubMed]

18. Eckenwalder, J.E. Conifers of the World; Timber Press: Portland, OR, USA, 2009; p. 720.

19. Sullivan, A.R.; Schiffthaler, B.; Thompson, S.L.; Street, N.R.; Wang, X.-R. Interspecific plastome recombination reflects ancient reticulate evolution in Picea (Pinaceae). Mol. Biol. Evol. 2017, 34, 1689-1701. [CrossRef] [PubMed]

20. Kulinich, O.A.; Orlinskii, P.D. Distribution of conifer beetles (Scolytidae, Curculionidae, Cerambycidae) and wood nematodes (Bursaphelenchus spp.) in European and Asian Russia. Bull. OEPP/EPPO Bull. 1998, 28, 39-52. [CrossRef]

21. Orlinski, A.D. Outcomes of the EPPO project on quarantine pests for forestry. Bull. OEPP/EPPO Bull. 2006, 36, 497-511. [CrossRef]

22. Vanhanen, H.; Veteli, T.; Niemelä, P. Potential distribution ranges in Europe for Ips hauseri, Ips subelongatus, and Scolytus morawitzi, a CLIMEX analysis. Bull. OEPP/EPPO Bull. 2008, 38, 249-258. [CrossRef]

23. FAO. Overview of Forest Pests, Kyrgyz Republic; Forest Health \& Biosecurity Working Papers, Working Paper FBS/21E; Food and Agriculture Organization of the United Nations: Rome, Italy, 2007; p. 64.

24. Cognato, A.I.; Sperling, F.A.H. Phylogeny of Ips DeGeer species (Coleoptera: Scolytidae) inferred from mitochondrial cytochrome oxidase I DNA sequence. Mol. Phylogenet. Evol. 2000, 14, 445-460. [CrossRef]

25. Zverev, M.D. Chronicle of the Alma-Ata State Reserve; Tr. Almaty State. Pres.: Almaty, Kazakhstan, 1947; Volume IV.

26. Ismukhambetov, J.D. Insect Pests of Tian-Shan Spruce and Their Control Measures; Kazakhstan Institute for Plant Protection and Quarantine: Almaty, Kazakhstan, 1976; p. 73. (In Russian) 
27. Merzlyakova, I. The mountains of Central Asia and Kazakhstan. In The Physical Geography of Northern Eurasia; Shahgedanova, M., Ed.; Oxford University Press: Oxford, UK, 2002; pp. 377-402.

28. Arkhipov, V.; Moukanov, B.M.; Khaidarov, K.; Goldammer, J.G. Overview on forest fires in Kazakhstan. Int. For. Fire News 2000, 22, 40-48.

29. Winchester, V.; Passmore, D.G.; Harrison, S.; Rae, A.; Severskiy, I.V.; Pimankina, N.V. Dendrogeomorphological and sedimentological analysis of debris flows hazards in the northern Zailiiskiy Alatau, Tien Shan Mountains, Kazakhstan. In Vulnerability of Land Systems in Asia; Braimoh, A.K., Huang, H.Q., Eds.; John Wiley and Sons: Chichester/West Sussex, UK, 2014; Volume 9, pp. 91-116.

30. Aizen, V.B.; Aizen, E.M.; Melack, J.M. Precipitation, melt and runoff in the northern Tien Shan. J. Hydrol. 1996, 186, 229-251. [CrossRef]

31. Blagovechshenskiy, V.P.; Yegorov, A.B. The Ile Alatau Range natural hazards. In Proceedings of the Materials of the International Conference on Mitigation of Natural Hazards in Mountain Areas, Bishkek, Kyrgyzstan, 15-18 September 2009; pp. 153-157.

32. Bolch, T.; Peters, J.; Yegorov, A.; Pradhan, B.; Buchroithner, M.; Blagoveshchensky, V. Identification of potentially dangerous glacial lakes in the northern Tian Shan. In Terrigenous Mass Movements; Pradhan, B., Buchroithner, M., Eds.; Springer: Berlin, Germany, 2012; pp. 369-398.

33. Yadav, R.R.; Kulieshius, P. Dating of earthquakes: Tree ring responses to the catastrophic earthquake of 1887 in Alma-Ata, Kazakhstan. Geogr. J. 1992, 158, 295-299. [CrossRef]

34. Beer, R.; Tinner, W. Four thousand years of vegetation and fire history in the spruce forests of northern Kyrgystan (Kungey Alatau, Central Asia). Veg. Hist. Archaeobot. 2008, 17, 629-638. [CrossRef]

35. Stokes, M.A.; Smiley, T.L. An Introduction to Tree-Ring Dating; University of Chicago Press: Chicago, IL, USA, 1968.

36. Applequist, M. A simple pith locator for use with off-center increment cores. J. For. 1958, 56, 141.

37. VoorTech. Measure J2X; Version 4.X; VoorTech Consulting: Holderness, NH, USA, 2010.

38. Holmes, R.L. Computer-assisted quality control in tree-ring dating and measurement. Tree-Ring Bull. 1983, 43, 69-78.

39. Grissino-Mayer, H.D. Research report evaluating crossdating accuracy: A manual and tutorial for the computer program COFECHA. Tree-Ring Res. 2001, 57, 205-221.

40. Veblen, T.T.; Hadley, K.S.; Reid, M.S.; Rebertus, A.J. Methods of detecting past spruce beetle outbreaks in Rocky Mountain subalpine forests. Can. J. For. Res. 1991, 21, 242-254. [CrossRef]

41. Eisenhart, K.S.; Veblen, T.T. Dendroecological detection of spruce bark beetle outbreaks in northwestern Colorado. Can. J. For. Res. 2000, 30, 1788-1798. [CrossRef]

42. Black, B.A.; Abrams, M.D. Use of boundary-line growth patterns as a basis for dendroecological release criteria. Ecol. Appl. 2003, 13, 1733-1749. [CrossRef]

43. Black, B.A.; Abrams, B.D. Development and application of boundary-line release criteria. Dendrochronologia 2004, 22, 31-42. [CrossRef]

44. Alfaro, R.I.; Campbell, R.; Vera, P.; Hawkes, B.; Shore, T.L. Dendroecological reconstruction of mountain pine beetle outbreaks in the Chilcotin Plateau of British Columbia. In Mountain Pine Beetle Symposium: Challenges and Solutions; Shore, T.L., Brooks, J.E., Stone, J.E., Eds.; Information Report BC-X-399; Natural Resources Canada, Canadian Forest Service, Pacific Forestry Centre: Victoria, BC, Canada, 2004; pp. 245-256.

45. Berg, E.E.; Henry, J.D.; Fastie, C.L.; De Volder, A.D.; Matsuoka, S.M. Spruce beetle outbreaks on the Kenai Peninsula, Alaska, and Kluane National Park and Reserve, Yukon Territory: Relationship to summer temperatures and regional differences in disturbance regimes. For. Ecol. Manag. 2006, 227, $219-232$. [CrossRef]

46. Sherriff, R.L.; Berg, E.E.; Miller, A.E. Climate variability and spruce beetle (Dendroctonus rufipennis) outbreaks in south-central and southwest Alaska. Ecology 2011, 92, 1459-1470. [CrossRef]

47. Janda, P.; Svoboda, M.; Bače, R.; Čada, V.; Peck, J.E. Three hundred years of spatio-temporal development in a primary mountain Norway spruce stand in the Bohemian Forest, central Europe. For. Ecol. Manag. 2014, 330, 304-311. [CrossRef]

48. O'Connor, C.D.; Lynch, A.M.; Falk, D.A.; Swetnam, T.W. Post-fire forest dynamics and climate variability affect spatial and temporal properties of spruce beetle outbreaks on a Sky Island Mountain range. For. Ecol. Manag. 2015, 336, 148-162. [CrossRef] 
49. White, P.B.; van de Gevel, S.L.; Soulé, P.T. Succession and disturbance in an endangered red spruce-Fraser fir forest in the southern Appalachian Mountains, North Carolina, USA. Endanger. Species Res. 2012, 18, 17-25. [CrossRef]

50. SPSS. PASW Statistics for Windows; Version 18.0; SPSS Inc.: Chicago, IL, USA, 2009.

51. Fettig, C.J.; Klepzig, K.D.; Billings, R.F.; Munson, A.S.; Nebeker, T.E.; Negrón, J.F.; Nowak, J.T. The effectiveness of vegetation management practices for prevention and control of bark beetle infestations in coniferous forests of the western and southern United States. For. Ecol. Manag. 2007, 238, 24-53. [CrossRef]

52. Lynch, A.M. What tree-ring reconstruction tells us about conifer defoliator outbreaks. In Insect Outbreaks Revisited; Barbosa, P., Letourneau, D.K., Agrawal, A.A., Eds.; Wiley-Blackwell: Chichester/West Sussex, UK, 2012; pp. 126-154.

53. Veblen, T.T.; Hadley, K.S.; Nel, E.M.; Kitzberger, T.; Reid, M.; Villalba, R. Disturbance regime and disturbance interactions in a Rocky Mountain subalpine forest. J. Ecol. 1999, 82, 125-135. [CrossRef]

54. Zhang, Q.; Alfaro, R.I.; Hebda, R.J. Dendroecological studies of tree growth, climate and spruce beetle outbreaks in central British Columbia, Canada. For. Ecol. Manag. 1999, 121, 215-225. [CrossRef]

55. Sanyang, F. The eco-geographical distribution of forest insects in China. J. Northeast For. Univ. 1992, 3, 13-22.

56. Ji, L.; Wang, Z.; Wang, X.; An, L. Forest insect pest management and forest management in China: An overview. Environ. Manag. 2011, 48, 1107-1121. [CrossRef]

57. FAO. Global Review of Forest Pests and Diseases; Forestry Paper 156; Food and Agriculture Organization of the United Nations: Rome, Italy, 2009; p. 235.

58. Kazenas, V.L.; Temrshev, I.I.; Esenbekova, P.A. Review of the sanitary state of coniferous forests in the wind fields in the Ile-Alatau State National Natural Park (Kazakhstan) in 2011-2015. Nat. Conserv. Res. 2016, 1, 23-37. (In Russian) [CrossRef]

59. Schlyter, F.; Birgersson, G.; Byers, J.A.; Löfqvist, J.; Bergström, G. Field response of spruce bark beetle, Ips typographus, to aggregation pheromone candidates. J. Chem. Ecol. 1987, 13, 701-716. [CrossRef]

60. Valkama, H.; Räty, M.; Niemelä, P. Catches of Ips duplicatus and other non-target Coleoptera by Ips typographus pheromone trapping. Entomol. Fenn. 1997, 8, 153-159. [CrossRef]

61. Byers, J.A.; Schlyter, F.; Birgersson, G.; Francke, W. E-myrcenol in Ips duplicatus: An aggregation pheromone component new for bark beetles. Experientia 1990, 46, 1209-1211. [CrossRef]

62. Duduman, M.-L.; Olenici, N. Non-target bark beetles in Ips duplicatus (Sahlberg) pheromone traps baited with host volatiles. Not. Bot. Horti Agrobot. Cluj-Napoca 2015, 43, nbha4329856.

63. Lebed, L. Possible changes in agriculture under the influence of climate change in Kazakhstan. In Environmental Problems of Central Asia and their Economic, Social and Security Impacts; Qi, J., Evered, K.T., Eds.; Springer Science: Dordrecht, The Netherlands, 2008; pp. 149-162.

64. Smirnova, E.Y.; Dolgikh, S.A.; Monkaeva, G.E.; Ilyakova, R.M.; Baybazarov, D.K. Annual Bulletin of Climate Change Monitoring in Kazakhstan: 2016; Ministry of Energy of the Republic of Kazakhstan, Scientific Research Center: Astana, Kazakhstan, 2017; p. 53.

65. Panyushkina, I.P.; Mukhamadiev, N.S.; Lynch, A.M.; Ashikbaev, N.A.; Arizpe, A.H.; O'Connor, C.D.; Abjanbaev, D.; Mengdbayeva, G.Z.; Sagitov, A.O. Wild apple growth and climate change in southeast Kazakhstan. Forests 2017, 8, 406. [CrossRef]

66. Werner, R.A.; Raffa, K.F.; Illman, B.L. Dynamics of phytophagous insects and their pathogens in Alaskan boreal forests. In Alaska's Changing Boreal Forest; Chapin, F.S., Oswood, M.W., Van Cleve, K., Eds.; Oxford University Press: New York, NY, USA, 2006; pp. 133-146.

67. Six, D.L.; Bracewell, R. Dendroctonus. In Bark Beetles: Biology and Ecology of Native and Invasive Species; Vega, F.E., Hofstetter, R.W., Eds.; Academic Press: London, UK, 2015; pp. 305-350.

68. Schroeder, L.M. Tree mortality by the bark beetle Ips typographus (L.) in storm-disturbed stands. Integr. Pest Manag. Rev. 2001, 6, 169-175. [CrossRef]

69. Dzhangaliev, A.D. The wild apple tree of Kazakhstan. In Horticultural Reviews: Wild Apple and Fruit Trees of Central Asia; John Wiley \& Sons, Inc.: Hoboken, NJ, USA, 2003; Volume 29, pp. 63-303.

70. Petrova, E.E.; Ilyakova, R.M.; Dolgiky, S.A.; Smirnova, E.Y. Annual Bulletin of Climate Change Monitoring in Kazakhstan: 2012; Ministry of Environmental Protection of the Republic of Kazakhstan: Astana, Kazakhstan, 2013; p. 37.

71. Swetnam, T.W.; Lynch, A.M. Multicentury, regional-scale patterns of western spruce budworm outbreaks. Ecol. Monogr. 1993, 63, 399-424. [CrossRef] 
72. Panyushkina, I.P.; Meko, D.M.; Macklin, M.G.; Toonen, W.H.J.; Mukhamadiev, N.S.; Konovalov, V.G.; Ashikbaev, N.Z.; Sagitov, A.O. Runoff variations in Lake Balkhash Basin, Central Asia, 1779-2015, inferred from tree rings. Clim. Dyn. 2018, 51, 3161-3177. [CrossRef]

73. Zhang, R.; Shang, H.; Yu, S.; He, Q.; Yuan, Y.; Bolatov, K.; Mambetov, B. Tree-ring-based precipitation reconstruction in southern Kazakhstan, reveals drought variability since A.D. 1770. Int. J. Clim. 2017, 37, 741-750. [CrossRef]

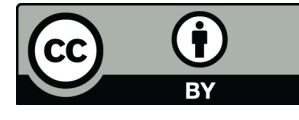

(C) 2019 by the authors. Licensee MDPI, Basel, Switzerland. This article is an open access article distributed under the terms and conditions of the Creative Commons Attribution (CC BY) license (http://creativecommons.org/licenses/by/4.0/). 